\title{
Mycobacterial infections in carcasses of ruminants slaughtered at the two slaughterhouses of Kassala, Sudan
}

\author{
Yassir A. Shuaib ${ }^{1,2,3 *}$ Stefan Niemann ${ }^{1}$ \\ Eltahir A. G. Khali1 ${ }^{4}$ Ulrich Schaible ${ }^{1}$ Lothar H. Wieler ${ }^{3,5}$ \\ Mohammed A. Bakheit ${ }^{6}$ Saad E. Mohamed-Noor ${ }^{2}$ \\ Mohamed A. Abdalla ${ }^{2}$ Elvira Richter ${ }^{1,7}$
}

\section{Keywords}

Ruminant, Mycobacterium, tuberculosis, slaughterhouse, Sudan

Submitted: 2 January 2017

Accepted: 29 January 2018

Published: 23 April 2018

DOI : $10.19182 /$ remvt.31530

\begin{abstract}
Summary
Tuberculosis (TB) is a chronic bacterial disease of humans and animals. It is characterized by the progressive development of specific granulomatous lesions in affected organs. Human TB is endemic in EasternSudan. However, knowledge on the epidemiology of TB in ruminants is scarce. In a six-month study from June to November 2014, a total of 2304 carcasses of cattle, sheep, goats and camels slaughtered at the East and West Gaash slaughterhouses of Kassala were inspected to investigate TB prevalence. Only $0.1 \%(n=2)$ of the carcasses had suspicious TB lesions. These lesions were solely found in carcasses of sheep, in the liver, lungs, and peritoneal cavity. The samples collected from the lesions were investigated for the presence of mycobacteria, which were found in one of the two carcasses. The grown bacteria were subjected to a line probe assay (GenoType Mycobacterium CM), and to $16 \mathrm{~S}$ rDNA and ITS gene sequencing, and whole genome sequencing (WGS). However, none of these methods identified this isolate as a valid Mycobacterium species. Nevertheless, 16S sequence allocated this isolate to slow growing mycobacteria. Neither Mycobacterium bovis nor M. caprae nor M. tuberculosis were found in the collected granulomatous lesions. In conclusion, the overall prevalence of TB-suggestive lesions in ruminants in Kassala was very low. Extended studies combining the use of a tuberculin skin test and slaughterhouse-based investigations should be adopted for TB surveillance in ruminants in Sudan.
\end{abstract}

- How to quote this article: Shuaib Y.A., Niemann S., Khalil E.A.G., Schaible U., Wieler L.H., Bakheit M.A., Mohamed-Noor S.E., Abdalla M.A., Richter E., 2017. Mycobacterial infections in carcasses of ruminants slaughtered at the two slaughterhouses of Kassala, Sudan. Rev. Elev. Med. Vet. Pays Trop., 70 (4): 131-136, doi: $10.19182 /$ remvt.31530
1. Research Center Borstel, Parkallee 1-40, 23845 Borstel, Germany.

2. College of Veterinary Medicine, Sudan University of Science and Technology,

Khartoum, Sudan.

3. Institute of Microbiology and Epizootics, Freie Universität Berlin, Berlin, Germany.

4. Institute of Endemic Diseases, University of Khartoum, Khartoum, Sudan.

5. Robert Koch Institute, Berlin, Germany.

6. Faculty of Veterinary Medicine, University of Khartoum, Khartoum, Sudan.

7. Labor Limbach, Heidelberg, Germany.

* Corresponding author

Tel.: +49 453718827 50; Email: vet.aboamar@gmail.com

\section{INTRODUCTION}

Tuberculosis (TB) is a chronic infectious disease of both humans and animals. It is characterized by progressive development of granulomatous lesions in affected tissues and organs (Shitaye et al., 2006; Theon et al., 2006). TB is caused by slow growing non-pigmented bacilli that belong to the Mycobacterium tuberculosis complex (MTBC). Mycobacterium bovis, M. caprae, and M. tuberculosis are responsible for causing TB in cattle, goats, and humans respectively and occasionally in other animal species (Malone et al., 2003; Smith et al., 2006; Radostits et al., 2007; Marianelli et al., 2010; Mamo et al., 2011). Moreover, different species of non-tuberculous mycobacteria are able to cause infections in different species of animals (Radostits et al., 2007; Asil et al., 2013; Aljameel et al., 2014). 
Worldwide prevalence of TB in cattle and other ruminants varies greatly by region and country. The disease has been effectively controlled in many countries but it is still prevalent in many others (Schiller et al., 2010). In Africa, around $85 \%$ of cattle and $82 \%$ of human populations live in areas where bovine TB is poorly controlled. In these areas, zoonotic TB caused by M. bovis is common (Ayele et al., 2004; Smith et al., 2006; Kulchavenya, 2014). Human TB is endemic in Eastern Sudan, however, knowledge on the prevalence of TB in ruminants is scarce and its epidemiology is not very well understood. This is attributed to the lack of systemic surveys and monitoring programs (Asil et al., 2013). Inadequate animal health infrastructures, traditional extensive grazing system for rearing animals, and a lesser interest in TB are other significant reasons (Asil et al., 2013; Ehsan and Nganwa, 2014).

Several diagnostic techniques can be used to investigate TB prevalence in livestock and to understand better its epidemiology and dynamics (Ramos et al., 2015). Tuberculin skin test and postmortem inspection remain the most important and economically affordable techniques, especially in resource-limited countries (Schiller et al., 2010; Ramos et al., 2015). Recently, few studies have investigated the prevalence of TB-suggestive lesions in cattle carcasses in the central and western parts of Sudan (Osman, 2007; Manal et al., 2010; Asil et al., 2013; Ehsan and Nganwa, 2014; Aljameel et al., 2014). The aim of the present study was to provide a better understanding of the epidemiology of TB and other mycobacterial infections in carcasses of ruminants slaughtered in Kassala in Eastern Sudan, as well as to identify the Mycobacterium species causing the infections.

\section{MATERIALS AND METHODS}

\section{Study area}

Kassala State is located in the eastern part of Sudan at latitude $14^{\circ}-17^{\circ} \mathrm{N}$, and longitude $34^{\circ}-37^{\circ} \mathrm{E}$ (Figure 1). It is delimited by a border with Eritrea (235 kilometers) in the east, and by national borders with the Red Sea State in the north, Khartoum State and the River Nile State in the west, and Al-Gadarif State in the southwest. It covers an area of 42,282 square kilometers. It falls within the Sahelian climate zone of Africa. Soils are dark, heavy, deep cracking Vertisol. Rainfall is concentrated in a single relatively short autumn season from June to September and reaches about 680 millimeters per year. Temperature ranges from a mean minimum of $17^{\circ} \mathrm{C}$ in January to a mean maximum of $47^{\circ} \mathrm{C}$ in April and May (Sulieman and Buchroithner, 2006). During the rainfall season, Kassala State is rich in fodder, grazing areas, by-products of sorghum and sesame. Moreover, the State has abundant amounts of water. Gaash, Siteet

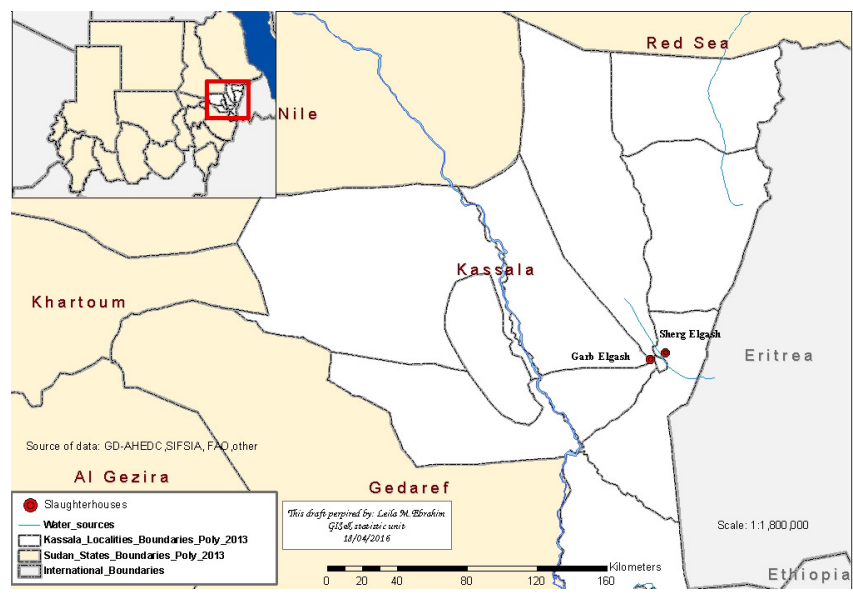

Figure 1: Location of the study area in Eastern Sudan. and Atbrah seasonal rivers, and Halfa Al-Gadeeydah canal are full of water during the rainfall season. Port Sudan, the main port for exportation of livestock and livestock products, is located 575 kilometers to the northeast of Kassala. Mixed crop-livestock, nomadic and semi-nomadic production systems predominate in the State. Animals are bred in Kassala for domestic consumption and for exportation to international markets (Omar et al., 2009). The State has an estimated livestock population of about 4.5 million head (MARF, 2008).

\section{Study design, sample size and sampling}

A cross-sectional study was conducted from June to November 2014 in Kassala State. This State was selected as it is one of the animal production sites in Sudan. The main town of the State has two slaughterhouses: East and West Gaash. On average, around 7500 head of animals are slaughtered per month in these slaughterhouses, among which about 2500 cattle, 4000 sheep, 950 goats, and 50 camels. The two slaughterhouses were conveniently included in this survey.

The sample size (n) was calculated based on the standard formula of Thrusfield (2007). The parameters of the formula were as follows: $95 \%$ confidence level, $\pm 5 \%$ desired level of precision, an assumed expected prevalence of $50 \%$ as the prevalence of TB in ruminants was unknown in Kassala. We used:

$$
\mathrm{n}=\frac{(1.96)^{2} \times \mathrm{P}^{\exp } \times\left(1-\mathrm{P}^{\exp }\right)}{\mathrm{d}^{2}}
$$

where $\mathrm{n}$ was the required sample size, $(1.96)^{2}$ the constant, $\mathrm{P} \exp$ the expected prevalence rate of $50 \%$, and $\mathrm{d}$ the desired precision level of $\pm 5 \%$.

The required sample size $\mathrm{n}$ was determined to be 384 animals from each of the two slaughterhouses. This number was inflated threefold to account for the effect of randomness and representativeness (Thrusfield, 2007). Thus, total $\mathrm{n}$ was 1152 animals from each slaughterhouse.

Convenient stratification according to species and systematic random sampling were used to select animals (Thrusfield, 2007). Selected animals were identified using permanent markers, kept in a separate place and released for slaughter one after another. The sampling interval was obtained by dividing the total number of slaughtered animals on that day by the estimated daily sample size (Thrusfield, 2007). Four animals were selected each study day from each of the four species. Each of the two slaughterhouses was visited 72 times (three visits per week). Therefore, the total number of animals slaughtered on a particular day from a particular species was divided by four and every $\mathrm{n}^{\text {th }}$ animal was selected after random selection of the first animal. Accordingly, n comprised a total of 710 cattle, 729 sheep, 700 goats, and 165 camels. Fewer than four camels were slaughtered per day in each slaughterhouse. To account for this, the required $\mathrm{n}$ per day was achieved by selecting more animals from other species.

\section{Postmortem inspection}

Postmortem inspection was performed as described by Corner et al. (1990), and Corner (1994). This included visual inspection, palpation and in situ slicing of lymph nodes, organs of the thoracic and abdominal cavities, and the head. Additionally, lymph nodes of the fore and hind limbs and the inguinal region were also inspected.

\section{Laboratory procedures}

Samples that were collected from the suspected granulomatous lesions were frozen at $-20^{\circ} \mathrm{C}$ until shipping to the National Reference Laboratory (NRL) for mycobacteria, Research Center Borstel (FZB), Germany. At NRL, samples were minced, then homogenized and 
decontaminated using sodium hydroxide, and the mucolytic agent $\mathrm{N}$-acetyl-L-cysteine (NALC-NaOH) according DIN's guidelines (2011). Smears were prepared from the decontaminated and resuspended specimens according to Kinyoun's method in conjunction with an automated staining system (ZN Aerospray TB Slide Stainer/ Cytocentrifuge, Wescor, Logan, USA). Moreover, cultures were made by inoculation into a mycobacteria-growth indication tube (MGIT) liquid medium (Bactec MGIT 960 system) (Becton-Dickinson, Heidelberg, Germany) and onto solid Löwenstein-Jensen and Stonebrink media (own production). Cultures were incubated at $37^{\circ} \mathrm{C}$ and $31^{\circ} \mathrm{C}$ for six (MGIT) or eight (solid media) weeks, respectively.

For molecular characterization of the isolate of the positive cultures, DNA was extracted with Tris-EDTA (TE) boiling/sonication extraction technique or the cetyltrimethylammonium bromide (CTAB) method, respectively. Commercially available line probe assay (LPA) (GenoType Mycobacterium CM, HAIN Lifescience GmbH, Nehren, Germany) and 16S rDNA and ITS gene sequencing were conducted from TE buffer prepared samples. In addition, whole genome sequencing (WGS) was carried out with Illumina MiSeq sequencer, Nextera XT library preparation kits, and MiSeq reagent kits according to the manufacturer's instructions (Illumina, San Diego, CA, USA). Classification of the reads was done by Kraken and reads were mapped to the $M$. tuberculosis H37Rv genome and $M$. intracellulare MOTT-64 with the exact alignment program Saruman.

\section{Prediction of the complete sequence of $16 \mathrm{~S}$ gene by WGS}

To predict the complete sequence of $16 \mathrm{~S}$ gene, de novo genome assembly was carried out. Reads were trimmed with Trimmomatic version 0.35 for Q30 in a sliding window of $20 \mathrm{bp}$ and nextera adapter contamination discarding all reads shorter than 100 bp (Bolger et al., 2014). Trimmed paired and unpaired reads were assembled with SPAdes version 3.6.2 using the built-in read error correction based on k-mer frequencies and the 'careful' option (Bankevich et al., 2012; Caverly et al., 2016). The $16 \mathrm{~S}$ gene sequence was predicted by the RNAmmer Prediction Server from the assembled contigs which were filtered for containing ribosomal sequences (Lagesen et al., 2007).

\section{RESULTS}

In total 40,089 animals were slaughtered in the two surveyed slaughterhouses during the study period. More than three quarters (81.0\%) were slaughtered at East Gaash slaughterhouse and 19.0\% at West Gaash. The male to female ratio was 1:1 for cattle, goats and camel, whereas it was 1:2 for sheep. Only animals older than one year in the case of cattle, sheep and goats, and older than five years in the case of camels had been slaughtered. The animals were mostly of indigenous breeds, e.g. Gaash cattle, and Garrage, Dubassy and Gaash sheep, Baladi, Garrage and Nubi goats, and Bushari and Anaafy camels. A few were exogenous from Eritrea and Ethiopia, e.g. Karour and Barka cattle, and Arrit and Horro sheep.

The overall prevalence of granulomatous lesions in all inspected carcasses was $0.1 \%(2 / 2304)$. The two carcasses that had suggestive TB lesions were carcasses of sheep. No TB-suggestive lesions were detected in carcasses of cattle $(0 / 710)$, goats $(0 / 700)$, and camels $(0 / 165)$. The detected granulomatous lesions were typical caseous necrosis, with a whitish or yellowish color. They were of various sizes congregating together, or scattered and enclosed in light congested grey fibrous tissue. They were found in the liver and lungs, and in the peritoneal cavity covering the whole abdomen and viscera (Figure 2).

Cultures revealed growth of mycobacteria from samples collected from one carcass. Samples collected from the other carcass were extensively contaminated with bacteria and yeast, and no mycobacterial growth could be found. Furthermore, MTBC isolates including $M$. bovis, $M$. caprae, and $M$. tuberculosis could not be grown from any of the samples.

LPA revealed a banding pattern (bands 1, 2, 3, and 10) that was not specific for any of the mycobacterium species identified by the assay (Figure 3). Moreover, 16S rDNA and ITS sequences of the isolated mycobacteria did not align with any known validly described $\mathrm{Myco}$ bacterium species in NCBI Blast database.

The fully sequenced genome had $4.8 \mathrm{mbp}$. Metagenomics classification by Kraken showed that $71.6 \%$ of the reads were unclassified and the closest relative was Mycobacterium sinense JDM601. Moreover, Kraken showed that only $0.2 \%$ and $0.1 \%$ of the sequenced genome was identical to the genome of M. tuberculosis $\mathrm{H} 37 \mathrm{Rv}$ and M. intracellulare MOTT-64, respectively.

The complete sequence of $16 \mathrm{~S}$ allocated this isolate to slow growing mycobacteria with the closest similarity to members of the M.terrae group. The alignment of the sequence of $16 \mathrm{~S}$ in the NCBI Blast database is shown in Figure 4.
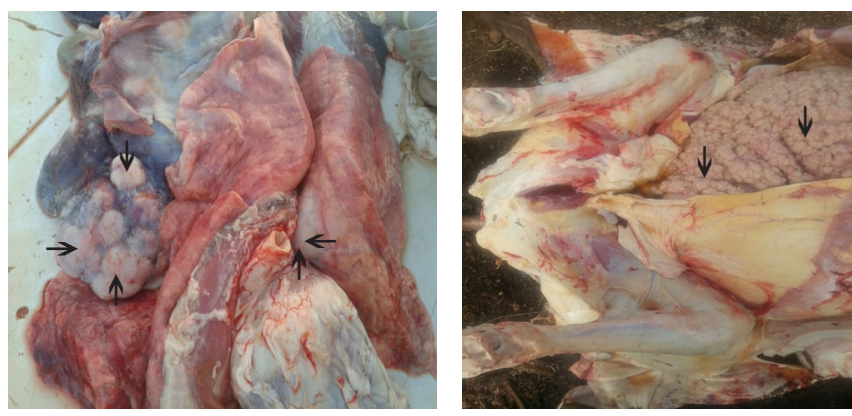

Figure 2: Granulomatous lesions in the liver and lungs (left), and peritoneal cavity (right) of two carcasses of slaughtered sheep in Eastern Sudan.

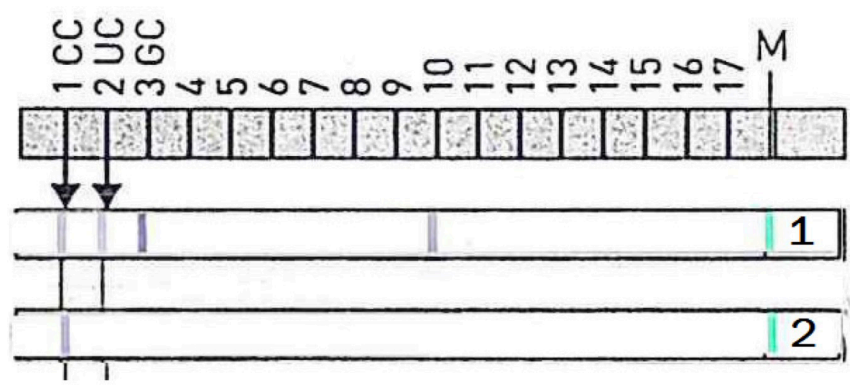

Figure 3: LPA (GenoType Mycobacterium CM) showing the unique banding pattern of the unknown Mycobacterium species isolated from the granulomatous lesions collected from a carcass of a slaughtered sheep in Eastern Sudan; 1: isolate; 2: negative control.

\section{DISCUSSION}

TB and other mycobacterial infections in animals are economically significant. The consequential production losses from these infections include lower milk production, loss of body weight, and condemnation of infected organs and carcasses. Animal reproduction and breeding as well as livestock trade at national and international levels are directly and adversely affected by mycobacterial infections (Radostits et al., 2007; Ehsan and Nganwa, 2014; Ramos et al., 2015). TB and other mycobacterial infections are quite prevalent in dairy 


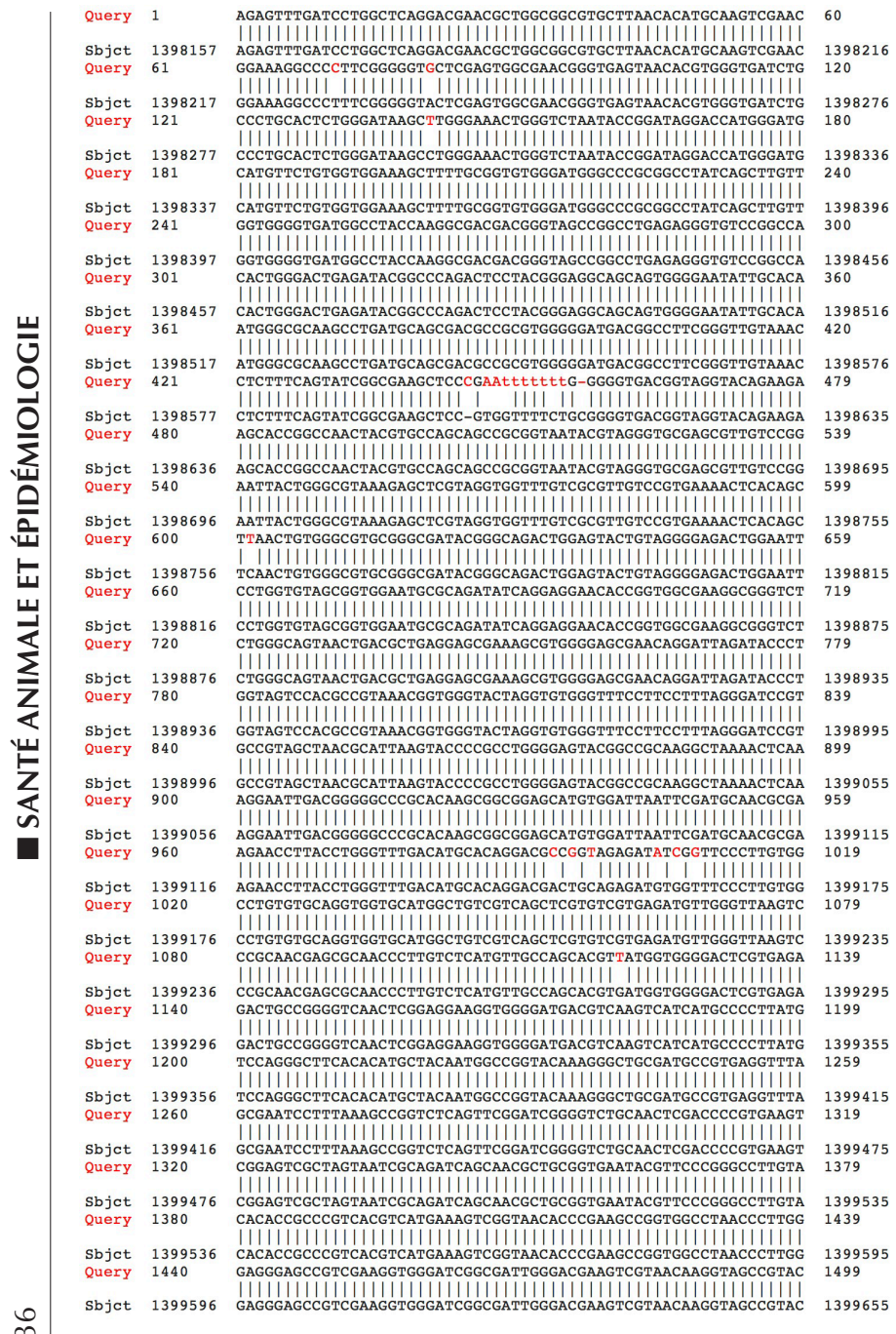

Figure 4: Alignment of the $16 S$ rRNA gene sequence of the isolate (Query) and Mycobacterium sinense strain JDM601 (Sbjct) sampled from the carcass of a slaughtered sheep in Eastern Sudan.

and meat animals in countries where control and management measures are not in place (Cousins, 2001; Humblet et al., 2009).

This study revealed a very low prevalence of granulomatous lesions $(0.1 \%)$ in carcasses of cattle, sheep, goats, and camels slaughtered at the two slaughterhouses of Kassala in Eastern Sudan. Overall in Sudan, the prevalence of granulomatous lesions suggestive of TB in slaughtered ruminant carcasses has been reported to range from $0.01 \%$ to $8.0 \%$ in different parts of the country. Lesions have been found in organs or lymph nodes, or generalized in the whole carcass (Manal et al., 2010; Asil et al., 2013; Aljameel et al., 2014; Ehsan and Nganwa, 2014). With the exception of one study that reported a small number of dairy cattle (11/569) that were positive by the tuberculin skin test in Eastern Sudan (Ayman et al., 2014), prevalence of TB in dairy and fattening farms has not been investigated in Sudan. Moreover, in neighboring and other African countries, prevalence of granulomatous lesions in slaughtered food animal carcasses has been up to 16\% (Mohamed et al., 2009; Biffa et al., 2010; Manal et al., 2010; Kassa et al., 2012; Youssef and Ahmed, 2014; Okoro et al., 2014; Worku and Abreham, 2016; Nalapa et al., 2017).

Different Mycobacterium species have been isolated from granulomatous lesions collected from carcasses in Sudan and elsewhere. The main identified bacteria are M. bovis, M. farcinogenes, M. tuberculosis, M. avium, and Nocardia species. Unidentified rapidly and slowly growing mycobacterium species have also been detected (Sulieman and Hamid, 2002; Oloya et al., 2007; Osman, 2007; Manal et al., 2010; Asil et al., 2013; Aljameel et al., 2014; Nalapa et al., 2017). Environmental risk factors, malnutrition, presence of other diseases, and heavy infestation with endoparasites are important factors that increase the susceptibility of animals to TB (Radostits et al., 2007; Ehsan and Nganwa, 2014). Environmental risk factors have not been investigated in this study; therefore, any solid conclusion regarding their effect in the low observed prevalence of granulomatous lesions could not be made. On the other hand, emaciated animals that are likely to have TB-suggestive lesions in their organs had been excluded during antemortem examination and were not slaughtered for human consumption, in accordance with public health and animal welfare regulations. Nonetheless, some of these excluded emaciated animals might be illegally slaughtered and prepared for human consumption. This practice is common in Sudan and is locally called 'Keery slaughtering'. TB-suggestive lesions might be more prevalent in carcasses of ruminants that are illegally slaughtered for human consumption.

Sensitivity of postmortem inspection for detection of TB-suggestive lesions in animal carcasses is between 28\% and 64\% (Biffa et al., 2010; Schiller et al., 2010; Okoro et al., 2014; Ramos et al., 2015; Worku and Abreham, 2016). However, this technique is cost-effective for passive surveillance and TB monitoring in animals. Besides, it is affordable in resource-limited countries (Schiller et al., 2010). The very low prevalence of TB-suggestive lesions in animal carcasses reported in this study could be attributed to the limited sensitivity of postmortem inspection. Furthermore, this study was conducted over a period of six months. Such period is short, especially in case of seasonal variations in the prevalence of animal TB. The sensitivity of the postmortem inspection technique is improved when animals are tested using the tuberculin skin test before slaughtering. Granulomatous lesions are likely to be detected in internal organs of animals that are positive by the tuberculin skin test. Moreover, extended slaughterhouse-based surveys should explore whether there are seasonal variations in the prevalence of granulomatous lesions suggestive of TB or not.

In this study, neither M. bovis nor M. caprae nor M.tuberculosis have been isolated from the detected granulomatous lesions. It suggests that zoonotic transmission of these mycobacteria from animals to humans via the consumption of contaminated meat is unlikely, although it cannot be completely ruled out, especially when the meat is prepared through unsupervised Keery slaughtering. A very slight potential risk of zoonotic transmission of unknown species of mycobacteria to humans via consumption of contaminated meat exists. It is not likely that local and international trade in livestock from Eastern Sudan is going to be restricted or hindered because of animal TB. Nevertheless, occurrence of this disease in animals that are reared on farms and in animals that are grazing in pastures should be monitored.

There is no control program directed against TB in animals in Kassala. Conversely, none of the carcasses inspected at the two slaughterhouses of Kassala had been infected with any of the MTBC bacteria. Radostits et al. (2007) indicate that the overall incidence and prevalence of TB are low in indigenous animals such as zebu type cattle and this might be due to natural resistance. Furthermore, these authors specify that low overall incidences of TB have also been observed in countries where cattle are at pasture all year round. These might probably explain the findings of this study. In Sudan, most of the slaughtered ruminants are indigenous breeds, and animals are at pasture for the whole year in search of fodder and water.

One of the strengths of this study was the investigation of a large number of different animal species at the two slaughterhouses of Kassala. Therefore, the findings might be generalized to the same animal species slaughtered and prepared for human consumption in other slaughterhouses in Eastern Sudan. Nonetheless, the study had limitations. No dairy farms have been investigated, hence, TB prevalence could 
not be compared between animals raised for meat and animals raised for milk. Additionally, the study was conducted in a short period. Perhaps TB prevalence was underestimated because of seasonal variations. Furthermore, only postmortem inspection was used as a mean to investigate $\mathrm{TB}$, but granulomatous lesions are small during early stages of the disease and might not be visible with naked eyes.

\section{CONCLUSION}

TB was not detected in carcasses of slaughtered ruminants in Kassala. This indicates that TB incidence in animals is very low in Kassala, and zoonotic transmission of MTBC bacteria is unlikely. One of the carcasses that was found with typical granulomatous lesions was infected with an unknown Mycobacterium species. This isolate could be pathogenic to humans. Slaughterhouse-based surveys combined with pre-slaughtering testing using the tuberculin skin test would help to explore TB epidemiology in animals in Sudan.

\section{Acknowledgments}

The authors wish to thank the Ministry of Animal Resources, Kassala, the Sudan, the Center Research Borstel, Borstel, Germany, and Dahlem Research School, Freie Universität Berlin, Berlin, Germany, for their contribution in accomplishing this work. The first author is a DAAD stipend recipient.

\section{REFERENCES}

Aljameel M.A., Abdel Wahab M.B., Fayza A.O., El Tigani A.E., Abdellatif M.M., 2014. Occurrence of bovine tuberculosis at Nyala abattoirs in South Darfur State, Sudan. Rev. Elev. Med. Vet. Pays Trop., 67 (2): 61-65, doi: 10.19182/remvt.10185

Asil T.A., El Sanousi S.M., Gameel A., El Beir H., Fathelrahman M., Terab N.M., Muaz M.A., et al., 2013. Bovine tuberculosis in South Darfur State, Sudan: an abattoir study based on microscopy and molecular detection methods. Trop. Anim. Health Prod., 45 (2): 469-72, doi: 10.1007/s11250012-0241-y

Ayele W.Y., Neill S.D., Zinsstag J., Weiss M.G., Pavlik I., 2004. Bovine tuberculosis: an old disease but a new threat to Africa. Int. J. Tuberc. Lung Dis., 8 (8): 924-937

Ayman E.A., Salih D.A., Gumaa M.M., Omer M.M., Abbas F., Ahmed A.M., 2014. Prevalence of bovine tuberculosis in Kassala State. Inter. J. Adv. Sci. Techn. Res., 4 (1): 238-249

Bankevich A., Nurk S., Antipov D., Gurevich A.A., Dvorkin M., Kulikov A.S., Lesin V.M., et al., 2012. SPAdes: a new genome assembly algorithm and its applications to single-cell sequencing. J. Com. Biol., 19 (5): 455-77, doi: $10.1089 / \mathrm{cmb} .2012 .0021$

Biffa D., Bogale A., Skjerve E., 2010. Diagnostic efficiency of abattoir meat inspection service in Ethiopia to detect carcasses infected with Mycobacterium bovis: Implications for public health. BMC Public Health, 10: 1-12, doi: 10.1186/1471-2458-10-462

Bolger A.M., Lohse M., Usadel B., 2014. Trimmomatic: a flexible trimmer for Illumina sequence data. Bioinformatics, 30 (15): 2114-20, doi: 10.1093/ bioinformatics/btu170

Caverly L.J., Spilker T., LiPuma J.J., 2016. Complete genome sequences of 17 rapidly growing nontuberculous mycobacterial strains. Genome Announc., 4 (5), doi: 10.1128/genomeA.01009-16

Corner L.A., 1994. Postmortem diagnosis of Mycobacterium bovis infection in cattle. Vet. Microbiol., 40 (1-2): 53-63, doi: 10.1016/03781135(94)90046-9

Corner L., Melville L., McCubbin K., Small K.J., McCormick B.S., Wood P.R., Rothel J.S., 1990. Efficiency of inspection procedures for the detection of tuberculous lesions. Aust. Vet. J., 67 (11): 389-92, doi: 10.1111/j.17510813.1990.tb03020.x

Cousins D.V., 2001. Mycobacterium bovis infection and control in domestic livestock. Rev. Sci. Tech. Off. Int. Epizoot., 20 (1): 71-85, doi: 10.20506/ rst.20.1.1263
DIN, 2011. Medical microbiology - Diagnosis of tuberculosis. Part 3: Detection of mycobacteria by culture methods. Deutsches Institut für Normung, Berlin, Germany

Ehsan A., Nganwa D., 2014. Factors contributing to the transmission of bovine tuberculosis caused by Mycobacterium bovis and its control status in Sudan. In: Zoonotic tuberculosis: Mycobacterium bovis and othe pathogenic mycobacteria, 3rd Edn (Eds Charles O.T., James H.S., John B.K.). John Wiley, USA

Humblet M.F., Boschiroli M.L., Saegerman C., 2009. Classification of worldwide bovine tuberculosis risk factors in cattle: a stratified approach. Vet. Res., 40 (5): 50, doi: 10.1051/vetres/2009033

Kassa G.M., Abebe F., Worku Y., Legesse M., Medhin G., Bjune G., Amen G., 2012. Tuberculosis in goats and sheep in Afar pastoral region of Ethiopia and isolation of Mycobacterium tuberculosis from Goat. Vet. Med. Int.: 869146, doi: 10.1155/2012/869146

Kulchavenya E., 2014. Extrapulmonary tuberculosis are statistical reports accurate. Ther. Adv. Infect. Dis., 2 (2): 61-70, doi: 10.1177/2049936114528173

Lagesen K., Hallin P., Rodland E.A., Staerfeldt H.H., Rognes T., Ussery D.W., 2007. RNAmmer: consistent and rapid annotation of ribosomal RNA genes. Nucleic Acids Res., 35 (9): 3100-8, doi: 10.1093/nar/gkm160

Malone F.E., Wilson E.C., Pollock J.M., Skuce R.A., 2003. Investigations into an outbreak of tuberculosis in a flock of sheep in contact with tuberculous cattle. Zoonoses Public Health, 50 (10): 500-504, doi: 10.1046/j.14390450.2003.00714.x

Mamo G., Bayleyegn G., Sisay Tessema T., Legesse M., Medhin G., Bjune G., Abebe F., et al., 2011. Pathology of camel tuberculosis and molecular characterization of its causative agents in pastoral regions of Ethiopia. PLoS One, 6 (1): e15862, doi: 10.1371/journal.pone.0015862

Manal H.S., Zakia A.M., El Eragi A.M., Hamaad H., 2010. Bovine tuberculosis at Omdurman Central Abattoir, Khartoum State and Wau slaughterhouses (Bahr El-Ghazal) State, Sudan. Sudan J. Vet. Res., 25: 1-8

MARF, 2008. Number of animals in the Sudan. Department of Information and Statistics, Ministry of Animal Resources and Fisheries, Khartoum, Sudan

Marianelli C., Cifani N., Capucchio M.T., Fiasconaro M., Russo M., La Mancusa F., Pasquali P., et al., 2010. A case of generalized bovine tuberculosis in a sheep. J. Vet. Diagn. Invest., 22 (3): 445-448, doi: $10.1177 / 104063871002200319$

Mohamed A.M., Abou El-Ella G.A., Nasr E.A., 2009. Phenotypic and molecular typing of tuberculous and nontuberculous Mycobacterium species from slaughtered pigs in Egypt. J. Vet. Diagn. Invest., 21 (1): 48-52, doi: 10.1177/104063870902100107

Nalapa D.P., Muwonge A., Kankya C., Olea-Popelka F., 2017. Prevalence of tuberculous lesion in cattle slaughtered in Mubende district, Uganda BMC Vet. Res., 13 (1): 73, doi: 10.1186/s12917-017-0991-x

Okoro O.J., Anosa G.N., Oboegbulem S.I., Nwanta J.A., Ezenduka E.V., 2014. Comparative assessment of postmortem inspection and immunochromatographic techniques for the detection of bovine tuberculosis in slaughter cattle in Nigeria. Trop. Anim. Health Prod., 46 (5): 831-6, doi: 10.1007/s11250-014-0573-x

Oloya J., Kazwala R., Lund A., Opuda-Asibo J., Demelash B., Skjerve E., Johansen T.B., et al., 2007. Characterisation of mycobacteria isolated from slaughter cattle in pastoral regions of Uganda. BMC Microbiol., 7: 95, doi: 10.1186/1471-2180-7-95

Omar H.E., Mohammad A.J., Babiker I.B., 2009. Constraints in the market chains for export of Sudanese sheep and sheep meat to the Middle East. CGSpace/ CGIAR, https://cgspace.cgiar.org/discover

Osman A.B., 2007. Caseation in lymph nodes of slaughtered cattle with a special reference to bovine tuberculosis. Vet. Med. J. Giza, 55: 1101-1109

Radostits O.M., Gay C.C., Blood D.C., Hinchelift K.W., 2007. Diseases associated with bacteria - IV - Mycobacterium spp. In: Veterinary medicine: A text book of disease of cattle, sheep, pig, goat and horses, $10^{\text {th }}$ Edn. Harcourt, London, UK, 1007-1044

Ramos D.F., Silva P.E.A., Dellagostin O.A., 2015. Diagnosis of bovine tuberculosis: review of main techniques. Braz. J. Biol., 75 (4): 830-837, doi: 10.1590/1519-6984.23613

Schiller I., Oesch B., Vordermeier H.M., Palmer M.V., Harris B.N., Orloski K.A., Buddle B.M., et al., 2010. Bovine tuberculosis: a review of current and emerging diagnostic techniques in view of their relevance for disease control and eradication. Transbound. Emerg. Dis., 57 (4): 205-20, doi: 10.1111/j.1865-1682.2010.01148.x 
Shitaye J.E., Getahun B., Alemayehu T., Skoric M., 2006. A prevalence study of bovine tuberculosis by using abattoir meat inspection and tuberculin skin testing data histopathological and IS 6110 PCR examination of tissues with tuberculous lesions in cattle in Ethiopia. Vet. Med. Czech., 51 (11): 512-522

Smith N.H., Gordon S.V., de la Rua-Domenech R., Clifton-Hadley R.S., Hewinson R.G., 2006. Bottlenecks and broomsticks: the molecular evolution of Mycobacterium bovis. Nat. Rev. Microbiol., 4 (9): 670-81, doi: 10.1038/nrmicro1472

Sulieman H.M., Buchroithner M.F., 2006. Assessment of natural vegetation clearing and re-growth in Southern Gadarif (Sudan) using change vector analysis based on remote sensing and field data. In: Proc. ISPRS Commission VII mid-term Symp., Remote sensing: From pixels to processes, Enschede, Netherlands, 8-11 May 2006
Sulieman M.S., Hamid M.E., 2002. Identification of acid-fast bacteria from caseous lesions in cattle in Sudan. J. Vet. Med. B, 49 (9): 415-418, doi: 10.1046/j.1439-0450.2002.00565.x

Theon C.O., Huchzermeyer H., Himies E.M., 2006. Mycobacterium bovis infection in animals and humans, $2 \mathrm{dn}$ Edn. Blackwell Publishing Professional, IA, USA, 63-72, doi: 10.1002/9780470344538

Thrusfield M., 2007. Veterinary epidemiology, 3rd Edn. Wiley-Blackwell Science, London, UK, 274-282

Worku A., Abreham S., 2016. Cross-sectional study and comparison of different diagnostic methods of bovine tuberculosis in Gondar Elfora abattoir, Ethiopia. Mycobact. Dis., 6 (3), doi: 10.4172/2161-1068.1000218

Youssef A.I., Ahmed A.M., 2014. Bovine tuberculosis survey based on meat inspection and microscopic examination in central city abattoir in Ismailia, Egypt, and its hazards to the abattoir workers. Inter. Food Res. J., 21 (2): 577-582

\section{Résumé}

Shuaib Y.A., Niemann S., Khalil E.A.G., Schaible U., Wieler L.H., Bakheit M.A., Mohamed-Noor S.E., Abdalla M.A., Richter $\mathbf{E}$. Infections mycobactériennes dans les carcasses de ruminants abattus dans les deux abattoirs de Kassala au Soudan

La tuberculose (TB) est une maladie bactérienne chronique chez les humains et les animaux. Elle se caractérise par le développement progressif de lésions granulomateuses spécifiques dans les organes affectés. La tuberculose humaine est endémique dans l'est du Soudan. Cependant, les connaissances sur l'épidémiologie de la tuberculose chez les ruminants sont rares. Dans le cadre d'une étude de six mois menée de juin à novembre 2014, 2304 carcasses de bovins, d'ovins, de caprins et de chameaux abattus dans les abattoirs de Gaash Est et Ouest de Kassala ont été inspectées afin d'enquêter sur la prévalence de la tuberculose. Seulement $0,1 \%(n=2)$ des carcasses présentait des lésions suspectes de tuberculose. Ces lésions n'ont été retrouvées que dans les carcasses de moutons, dans le foie, les poumons et la cavité péritonéale. Les échantillons prélevés sur les lésions ont été analysés pour détecter la présence de mycobactéries. Celles-ci ont été retrouvées dans l'une des deux carcasses. Cet isolat a été soumis à un test par sonde linéaire (GenoType Mycobacterium $\mathrm{CM}$ ) et à un séquençage de I'ADNr $16 \mathrm{~S}$ et du gène ITS, ainsi qu'à un séquençage du génome entier (WGS). Cependant, aucune de ces méthodes n'a permis d'identifier cette souche comme une espèce de Mycobacterium valide. Néanmoins, la séquence $16 \mathrm{~S}$ a attribué cet isolat à des mycobactéries à croissance lente. Ni Mycobacterium bovis, ni M. caprae ni M. tuberculosis n'ont été retrouvés dans les lésions granulomateuses collectées. En conclusion, la prévalence globale des lésions évocatrices de tuberculose chez les ruminants à Kassala était très faible. Des études approfondies combinant I'utilisation de tests cutanés à la tuberculine et des enquêtes menées dans les abattoirs devraient être conduites pour la surveillance de la tuberculose chez les ruminants au Soudan.

\section{Resumen}

Shuaib Y.A., Niemann S., Khalil E.A.G., Schaible U., Wieler L.H., Bakheit M.A., Mohamed-Noor S.E., Abdalla M.A., Richter E. Infecciones micobacterianas en carcasas de rumiantes sacrificados en dos mataderos de Kassala, Sudan

La tuberculosis (TB) es una enfermedad bacteriana crónica de humanos y animales. Se caracteriza por un desarrollo progresivo de lesionas granulomatosas específicas en los órganos afectados. La TB humana es endémica en el est de Sudan. Sin embargo, los conocimientos de la epidemiología de TB en rumiantes son raros. En un estudio de seis meses, de junio a noviembre 2014, 2304 carcasas de ganado, ovejas, cabras y camellos sacrificados en los mataderos de Gaash Este y Oeste en Kassala, fueron inspeccionadas para investigar la prevalencia de TB. Solamente $0,1 \%(n=2)$ de las carcasas presentaron lesiones sospechosas de TB. Estas lesiones solo se encontraron en carcasas de ovejas, en hígado, pulmones y cavidad peritoneal. Las muestras colectadas en estas lesiones fueron investigadas para la presencia de micobacteria. Se encontraron en una de las dos carcasas. Este aislamiento se sometió a un ensayo de sonda lineal (GenoType Mycobacterium CM), y a secuencias genéticas ITS y $16 \mathrm{~S}$ rDNA, así como secuencia genómica completa (WGS). Sin embargo, ninguno de estos métodos identificó esta cepa como una especie válida de Mycobacterium. No se encontró ni Mycobacterium bovis ni $M$. caprae ni $M$. tuberculosis en las lesiones granulomatosas colectadas. En conclusión, la prevalencia general de lesiones sugestivas de TB en rumiantes en Kassala fue muy baja. Estudios extensivos, combinando el uso del test de tuberculina dérmica y una investigación centrada en los mataderos, debe ser adoptarse para la supervisión de TB en los rumiantes de Sudan.

Palabras clave: rumiante, Mycobacterium, tuberculosis, matadero, Sudan

Mots-clés : ruminant, Mycobacterium, tuberculose, abattoir, Soudan 